\title{
PENGGUNAAN METODE IN THE NEWS UNTUK MENINGKATKAN KEMAMPUAN LITERASI INFORMASI SISWA DALAM PEMBELAJARAN SEJARAH \\ (Penelitian Tindakan Kelas di Kelas XI MIIA 2 SMA Kartika XIX-1 Bandung)
}

Oleh

Efik Mulyati dan Tarunasena ${ }^{1}$

\begin{abstract}
ABSTRAK
Skripsi ini berjudul "Penggunaan metode In The News untuk meningkatkan kemampuan literasi informasi siswa dalam pembelajaran sejarah (Penelitian Tindakan Kelas di Kelas XI MIIA 2 SMA Kartika XIX-1 Bandung)". Setelah melakukan observasi awal, permasalahan yang terjadi adalah rendahnya keterampilan literasi informasi siswa dalam pembelajaran sejarah. Hal ini terlihat dari kebiasaan siswa yang terpaku pada satu sumber informasi dalam mencari suatu topik tertentu berkaitan dengan materi ajar ataupun dalam menjawab soal yang guru berikan. Siswa juga tidak melakukan proses identifikasi terhadap baik atau tidaknya sumber informasi yang digunakan untuk menyelesaikan tugasnya. Selain itu, siswa tidak memiliki kemampuan mengolah informasi yang baik. Sebagian besar siswa menyalin langsung informasi yang didapatkannya dari sumber informasi untuk menyelesaikan tugasnya. Penelitian ini menggunakan metode penelitian tindakan kelas (PTK) dengan menggunakan desain penelitian dari Dave Ebbut. Melalui metode In The News guru menekankan siswa untuk mencari, mengolah, dan mengkomunikasikan berbagaimacam informasi dari sumber yang mereka gunakan. Berdasarkan analisis dari penelitian yang telah dilakukan, dengan perencanaan yang dilakukan oleh peneliti sebelum menerapkan metode In The News seperti observasi, dan merancang pembelajaran dengan menggunakan berbagai macam format dan media pembelajaran di setiap siklusnya, menunjukkan bahwa penggunaan metode In The News dapat meningkatkan keterampilan literasi informasi siswa dalam pembelajaran sejarah di kelas XI MIIA 2 SMA Kartika XIX1 Bandung. Hal ini terlihat dari meningkatnya pencapaian siswa dalam setiap pelaksanaan siklus, pengerjaan tugas, dan presentasi kelompok.
\end{abstract}

Kata kunci: penelitian tindakan kelas, metode In The News, keterampilan literasi informasi.

\begin{abstract}
This research entitled 'The use of in the news method to increase the students' ability on information literacy in history learning (Classroom action research in twelfth grade-MIIA 2, SMA Kartika XIX-1 Bandung)'. After conducting the initial observation, the problem that occurs is the low ability of the students' information

1 Penulis merupakan mahasiswa Departemen Pendidikan Sejarah, Fakultas Pendidikan Ilmu Pengetahuan Sosial, Universitas Pendidikan Indonesia dengan Tarunasena sebagai dosen Pembimbing II. Penulis dapat dihubungi melalui nomor $085795 \quad 666902$ atau email Efikmulyati_24@yahoo.co.id.
\end{abstract}


literacy. It can be seen through the students' habit that only concerns one resource in investigating a particular topic that relates to teaching material or in answering the questions given by the teacher. The students also do not exercise identification process on the goodness or the badness of the resource used to accomplish their assignments. Moreover, the students do not have the ability to process the information well. Most students directly copy the information obtained from the resource to finish their assignments. This study employs classroom action research with the use of Dave Ebbut's research design. Through in the news methodology, the teacher emphasizes the students to investigate, process, and communicate many kinds of information from the resources used by them. Based on the analysis of this research, it shows that the use of in the news method can increase the students' ability on information literacy in history learning in twelfth grade-MIIA 2, SMA Kartika XIX-1 Bandung. It can be seen from the enhancement of the students' achievement in every implementation of cycle, the work on assignment, and group presentation.

Keywords: classroom active research, in the news method, the ability of information literacy

\section{PENDAHULUAN}

Dengan kondisi kemajemukan etnis yang sangat beragam, kelemahan bangsa Indonesia dalam mencari dan memahami suatu informasi sangat berpengaruh terhadap kehidupan dalam bermasyarakat. Hal ini karena banyak terjadi kasus di mana terjadi bentrokkan atau kerusuhan antar masyarakat yang penyebabnya tidak jarang karena kesalahpahaman dalam menerima dan memahami informasi.

Menurut Gillin dan Gillin (1954) (dalam Poerwanto, 1997, hlm. 40 ) dinamika suatu rnasyarakat tercermin dalam perkembangan dan perubahan yang terjadi, yaitu akibat hubungan orang-perorangan, antar kelompok maupun antara orang perorangan dengan kelompok. Berbagai bentuk interaksi sosial yang ditandai oleh terjadinya kontak dan komunikasi, merupakan aspek penting untuk mempelajari proses-proses sosial. Berdasarkan teori di atas peneliti menyimpulkan bahwa hal ini tentu tidak terlepas dari rendahnya kemampuan dan keinginan masyarakat dalam mencari informasi.

Masyarakat sering disuguhi bacaan yang tidak jarang berisi berita atau informasi yang tidak benar, atau sering disebut dengan istilah hoax. Berita atau informasi hoax disebarluaskan oleh orang yang tidak bertanggungjawab dengan berbagai alasan yang di antaranya untuk mengadu domba, ataupun hanya ingin 
mendapatkan simpati dari orang banyak. Berita hoax banyak dijumpai di dalam dunia maya seperti di dalam blog, facebook, twitter, maupun media sosial lainnya. Dan yang menghawatirkan, berita hoax biasanya selalu mendapatkan banyak perhatian dari para pembacanya, entah itu karena kemasan beritanya yang dibuat menarik perhatian ataupun tema berita yang disuguhkan terkait dengan kehidupan masyarakat seperti tentang agama, kesehatan, ekonomi, politik, olahraga, dan lainnya. Mengapa masalah tentang literasi informasi ini layak untuk dibahas terutama dalam dunia pendidikan, karena pentingnya kemampuan literasi diungkapkan oleh Reza (tt, hlm. 2-3), LaQuey (dalam Sakti, 2014, hlm. 5), Supriatna (2007, hlm. 129) bahwa:

Siswa merupakan pengguna informasi yang berada di lingkungan akademik, yang tentunya kebutuhan akan informasinya berbeda dengan profesi atau pengguna informasi lainnya. Di sini siswa dituntut untuk memiliki kemampuan mengelolah pengetahuan yang sudah mereka miliki dan memanfaatkan pengetahuannya. Namun ada beberapa hal yang perlu diingat ketika mengakses informasi pada internet. Dalam alam nyata, tidak ada jaminan bahwa apa yang Anda dengar atau baca adalah seratus persen benar. Hal yang sama juga berlaku pada Internet. Tetapi, pada Internet Anda dapat memperoleh informasi dari berbagai sumber untuk dapat melakukan koreksi-silang dan membentuk opini Anda sendiri. Oleh karena itu keterampilan mencari, memilih, mengolah, dan menggunakan informasi untuk memberdayakan diri serta keterampilan bekerjasama dengan kelompok yang majemuk nampaknya merupakan aspek yang sangat penting dimiliki oleh siswa yang kelak akan menjadi warga negara dewasa dan berpartisipasi aktif di era global.

Dalam pembelajaran sejarah literasi informasi bisa diperoleh dari berbagai sumber seperti buku, dokumen-dokumen, arsip, surat kabar, bahkan benda-benda peninggalan zaman dahulu seperti prasasti atau lainnya. Yang paling digemari generasi masa kini terutama di kalangan anak sekolah adalah penggunaan internet untuk mencari segala sesuatu yang berhubungan dengan materi pelajaran di sekolah. Penggunaan internet akan sangat bermanfaat jika digunakan secara bijak, mengingat kemudahan untuk mencari informasi yang sangat luas dalam waktu yang relatif singkat juga 
dengan biaya yang lebih ekonomis jika dibandingkan dengan menggunakan buku atau sumber belajar lainnya. Namun yang menjadi permasalahan ialah ketika siswa cenderung terlena pada kemudahan mencari sumber belajar dari internet, sehingga buku paket pelajaran yang mereka punya hanya sedikit dipakai atau tidak dipakai sama sekali. Hal seperti ini peneliti temukan di kelas XI MIIA 2 SMA Kartika XIX-1 Bandung pada saat observasi awal.

Alasan dikemukakan oleh mereka yaitu karena dengan menggunakan internet jawaban yang diinginkan secara otomatis akan langsung terjawab, berbeda dengan menggunakan buku di mana mereka harus mencari dan membaca lembar perlembar yang itupun belum tentu sesuai dengan pertanyaan yang diajukan. Alasan dari para siswa tersebut memang dibenarkan oleh Djamarah (2008, hlm. 130) 'bahwa jika informasi yang diperlukan sudah ditentukan terlebih dahulu, efisiensi membaca akan lebih baik karena konsentrasi pikiran dan perhatian dapat diarahkan langsung pada informasi itu.'

Permasalahan yang dapat diambil yaitu mengenai literasi informasi di mana penggunaan sumber buku maupun internet sebagai sumber utama tanpa mencampurkan keduanya sebagai rujukan pendukung atau pembanding, kemudian siswa menyajikan informasi pada siswa lainnya tanpa mengolah informasi yang ia dapat sebelumnya terlebih dahulu.

Dari berbagai sumber yang menjelaskan tentang literasi informasi, bisa disimpulkan bahwa literasi informasi dimaknai sebagai kemampuan melakukan interpretasi yang di dalamnya berupa keterampilan mencari, memilih, mengolah, dan menggunakan informasi dari apa yang ia lihat.

Dalam hal ini kemampuan seseorang untuk mencari informasi sangatlah penting karena setiap informasi yang didapat belum tentu dapat dipertanggung jawabkan kebenaran isinya. Seperti yang dikemukakan oleh Darmawan bahwa : Untuk menempatkan informasi sebagai sumber belajar kita dihadapkan pada upaya untuk memvalidasi isi dan sumber informasi yang diperoleh. Adapun validasi sumber informasi dapat dilakukan dengan cara menelusuri lebih lanjut sumber dari mana atau siapa yang 
menjadi sumber munculnya informasi terkait (Darmawan, 2014, hlm 4).

Dari uraian di atas maka peneliti menentukan indikator kemampuan literasi informasi yang menjadi fokus dalam penelitian ini yaitu:

Tabel 1.1

Indikator Kemampuan Literasi Informasi

\begin{tabular}{|c|c|c|}
\hline No & Aspek & Indikator \\
\hline 1. & $\begin{array}{l}\text { Aspek } \\
\text { Pengetahuan }\end{array}$ & $\begin{array}{l}\text { Menggunakan teknologi digital untuk mengakses, dan } \\
\text { menciptakan informasi guna mengembangkan } \\
\text { pengetahuan: } \\
\text { - Siswa mencari informasi yang beragam } \\
\text { - Siswa menggunakan blog/internet sebagai sumber } \\
\text { informasi } \\
\text { - Siswa mampu menyeleksi informasi mana yang boleh } \\
\text { dan tidak boleh digunakan }\end{array}$ \\
\hline 2. & $\begin{array}{l}\text { Aspek } \\
\text { Kesadaran }\end{array}$ & $\begin{array}{l}\text { Menggunakan informasi yang dapat } \\
\text { dipertanggungjawabkan : } \\
\text { - Siswa menyeleksi informasi berdasarkan konfirmasi } \\
\text { atau diskusi dengan guru maupun teman sebaya } \\
\text { - Siswa mampu mencantumkan sumber informasi } \\
\text { dengan benar }\end{array}$ \\
\hline 3. & $\begin{array}{l}\text { Aspek } \\
\text { Keterampilan / } \\
\text { Tindakan }\end{array}$ & $\begin{array}{l}\text { Kemampuan untuk mengakses dan menggunakan } \\
\text { informasi dari berbagai sumber: } \\
\text { - Siswa dapat memanfaatkan sumber yang tersedia (buku } \\
\text { ataupun internet) } \\
\text { - Siswa dapat menulis dan merangkum informasi yang } \\
\text { dia dapat } \\
\text { - Siswa dapat mengkomunikasikannya pada orang lain } \\
\text { menggunakan bahasanya sendiri }\end{array}$ \\
\hline
\end{tabular}


Metode In The News sendiri menurut Silberman di sebut sebagai beritaberita utama adalah metode pembelajaran yang menjadikan peserta didik terlibat dan menumbuhkan ketertarikan mereka pada topik yang akan dibahas. Metode ini juga akan menghasilkan kekayaan materi dan informasi bagi peserta didik karena dalam metode ini peserta didik diharuskan mempunyai atau mencari informasi dari buku, surat kabar, artikel, dan sumber informasi lainnya (Silberman, 2010, hlm. 178)

Secara sederhana peningkatan literasi informasi melalui metode In The News yaitu peserta didik diajarkan dan diharuskan untuk mencari informasi yang berkaitan dengan tema pembelajaran dari berbagai sumber. Tidak hanya dari internet siswa juga diharuskan menggunakan sumber buku. Dan materi yang diambil dari internet pun harus materi yang sumber tulisan ataupun penulisnya jelas. Setelah itu dengan sistem tanya jawab dan diskusi siswa pun diharuskan agar informasi atau materi yang ia dapat, ditulis atau diutarakan menurut apa yang ia pahami dan dengan bahasanya sendiri. Hal ini akan menjadikan siswa lebih kritis dalam menanggapi sebuah informasi dan menjadikan siswa lebih aktif di dalam proses pembelajaran karena mau tidak mau siswa akan mengkritisi informasi yang ia dapatkan maupun yang siswa lain utarakan.

Intinya melalui metode In The News dapat meningkatkan literasi informasi yang mencakup keterampilan mencari informasi, keterampilan mengidentifikasi informasi, keterampilan mengolah informasi, dan keterampilan mengkomunikasikan informasi.

Variabel $\mathrm{X}$ dalam penelitian ini ialah metode pembelajaran yang akan digunakan yaitu metode In The News dan varibel Y dalam penelitian ini yaitu pengaruh terhadap peningkatan kemampuan literasi informasi.

\section{METODE PENELITIAN}

Metode yang digunakan dalam penelitian ini adalah metode Penelitian Tindakan Kelas (Classroom Action Research). Penelitian mengenai penerapan metode In The News untuk meningkatkan literasi informasi siswa dalam pembelajaran sejarah ini menggunakan metode Penelitian Tindakan Kelas (Classroom Action Research). Menurut menurut Mc Niff (1992) (dalam Kusumah dan 
Dwitagama, 2012, hlm. 8) informasi siswa dalam pembelajaran memandang hakikat PTK adalah sebagai bentuk penelitian reflektif yang dilakukan oleh guru sendiri yang hasilnya dapat dimanfaatkan sebagai alat untuk pengembangan keahlian mengajar. PTK merupakan penelitian tentang, untuk, dan oleh masyarakat atau kelompok sasaran dengan memanfaatkan interaksi, partisipasi dan kolaboratif antara peneliti dan kelompok sasaran. Adapun pengertian PTK adalah penelitian yang dilakukan oleh guru di kelasnya sendiri dengan cara (1) merencanakan,

melaksanakan, (3) merefleksikan tindakan secara kolaboratif dan partisipatif dengan tujuan memperbaiki kinerjanya sebagai guru, sehingga hasil belajar siswa dapat meningkat (Kusumah dan Dwitagama, 2012, hlm. 9).

\section{Dari berbagai pengertian} mengenai PTK di atas dan dilihat dari karakteristik PTK itu sendiri yang utamanya melakukan perubahan kearah perbaikan terhadap proses pembelajaran. Maka dari itu metode ini dirasa cocok digunakan untuk memperbaiki layanan kependidikan yang diselenggarakan dalam konteks pembelajaran di kelas, yaitu untuk meningkatkan kemampuan literasi sejarah. Adapun desain penelitian tindakan kelas yang akan digunakan dalam penelitian ini adalah desain yang dikembangkan oleh Dave Ebbut.

Dalam model Ebbut, suatu penelitian tindakan kelas setiap siklus dimungkinkan terdiri dari beberapa tindakan. Langkah kerja pengembangan model Ebbut ini hampir sama dengan langkah kerja model lainnya. Langkah kerja model tersebut dimulai dari penemuan masalah yang peneliti temukan ketika observasi pra penelitian, kemudian dirancang rencana yang dianggap mampu untuk memecahkan masalah tersebut yang peneliti tuangkan dalan RPP. Rencana tersebut kemudian diimplementasikan dalam bentuk tindakan, yang setiap siklus atau tindakannya peneliti melakukan berbagai variasi dalam segi materi, media, maupun strategi pembelajaran. Setelah itu dilakukan monitor untuk mengetahui apakah tindakan sesuai rencana awal dan selanjutnya dilakukan beberapa tindakan lagi sehingga pada akhirnya model ini akan membentuk sebuah kegiatan yang berulang (siklus). 
HASIL PENELITIAN DAN ketiga mengalami penurunan. Salah PEMBAHASAN satu faktor penurunan tersebut karena

Berdasarkan hasil dari siswa mulai merasa jenuh dan kurang penerapan merode In The News yang antusias dengan pembelajaran sejarah, dilakukan terhadap siswa kelas XI hal itu mungkin karena pada tindakan MIIA 2 diperoleh informasi bahwa ternyata rangkaian kegiatan yang terdapat pada metode In The News ini seperti pengerjaan tugas atau ulangan harian dalam buku paket sejarah dan presentasi ternyata dapat meningkatkan keterampilan literasi informasi dalam pembelajaran sejarah. Adapun analisis dari hal tersebut adalah sebagai berikut:

Berdasarkan deskripsi hasil pengolahan data terhadap pengerjaan tugas kelompok pada tindakan I dan II serta tugas individu pada tindakan I dalam siklus ketiga, maka dapat disimpulkan bahwa keterampilan literasi informasi siswa sudah dapat dikatakan baik. Namun peneliti mencoba untuk melaksanakan lagi kegiatan pengerjaan tugas kelompok pada siklus selanjutnya yakni siklus keempat. Hal ini karena meskipun pada siklus tiga mengalami peningkatan, namun pada tindakan tiga guru tidak menggunakan media seperti video atau powerpoint sehingga wajar saja jika siswa terlihat jenuh dan mengalami penurunan.

Siklus keempat dilaksanakan sebagai upaya perbaikan dari penurunan yang terjadi pada tindakan tiga siklus tiga, juga sebagai patokan sejauh mana peningkatan yang nantinya terjadi. Secara umum siswa tetap dapat mempertahankan pencapainan sebelumnya, meskipun tidak mengalami kenaikan secara jauh namun dapat dikatakan bahwa pencapaian literasi informasi siswa dalam pengerjaan tugas kelompok pada siklus IV ini sudah baik. Berikut akan disajikan diagram yang menggambarkan perkembangan presentase ketercapaian keterampilan literasi informasi yang dilihat melalui pengerjaan tugas siswa secara kelompok maupun individu pada siklus I hingga siklus IV: 


\section{Presentase Pencapaian Indikator Literasi Informasi Melalui Pemberian Tugas Individu dan Kelompok}

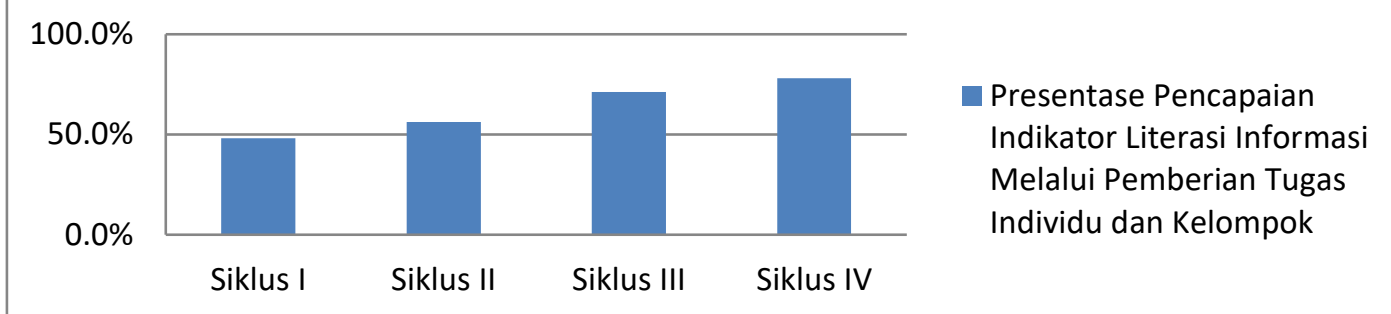

Gambar 1.1. Diagram Perkembangan Presentase Keterampilan Literasi Informasi Siswa Melalui Pengerjaan Tugas Individu dan Kelompok

Diagram di atas memaparkan mengenai presentase pencapaian indikator literasi informasi siswa yang di lihat melalui hasil pengerjaan tugas individu maupun kelompok. Pada siklus I presentase rata-rata penilaian keterampilan literasiinformasi siswa yang di lihat melalui pengerjaan soal dalam buku paket secara individu sebesar 48,2\% dan mengalami kenaikan pada siklus II menjadi 56,3\%. Pada siklus III juga mengalami kenaikan dari siklus sebelumnya, menjadi $71,3 \%$ dan pada siklus IV hasil akhirnya memperoleh $78 \%$.
Selain memaparkan secara umum hasil pengolahan data dengan merata-ratakan hasil skor perolehan setiap kelompok, peneliti juga akan memaparkan mengenai hasil pengolahan data setiap indikator keterampilan literasi informasi yang diamati melalui pengerjaan tugas individu maupun kelompok di setiap siklusnya. Dibawah ini merupakan tabel perolehan skor setiap indikator keterampilan literasi informasi siswa yang dilihat melalui pengerjaan tugas yang di paparkan secara kelompok: 
Tabel 1.2 Perolehan Skor Tiap Indikator Keterampilan Literasi Informasi yang Diamati Melalui Pemberian Tugas

\begin{tabular}{|c|c|c|c|c|c|c|c|c|c|c|c|c|}
\hline & \multicolumn{3}{|c|}{ Siklus I } & \multicolumn{3}{c|}{ Siklus II } & \multicolumn{3}{c|}{ Siklus III } & \multicolumn{3}{c|}{ Siklus IV } \\
\cline { 2 - 14 } Kelompok & \multicolumn{3}{|c|}{ Indikator } & \multicolumn{3}{c|}{ Indikator } & \multicolumn{3}{c|}{ Indikator } & \multicolumn{3}{c|}{ Indikator } \\
\cline { 2 - 14 } & $\mathbf{1}$ & $\mathbf{2}$ & $\mathbf{3}$ & $\mathbf{1}$ & $\mathbf{2}$ & $\mathbf{3}$ & $\mathbf{1}$ & $\mathbf{2}$ & $\mathbf{3}$ & $\mathbf{1}$ & $\mathbf{2}$ & $\mathbf{3}$ \\
\hline $\mathbf{1}$ & 4,14 & 2,57 & 4,00 & 5,24 & 3,38 & 4,57 & 6,95 & 3,81 & 6,43 & 7,29 & 4,71 & 7,14 \\
\hline $\mathbf{2}$ & 5,67 & 2,33 & 3,33 & 5,44 & 3,61 & 4,17 & 6,17 & 3,72 & 5,78 & 6,33 & 4,33 & 6,67 \\
\hline $\mathbf{3}$ & 5,14 & 2,71 & 3,29 & 5,52 & 3,57 & 4,76 & 6,71 & 4,19 & 6,14 & 7,00 & 4,29 & 7,00 \\
\hline $\mathbf{4}$ & 4,67 & 3 & 4,33 & 5,11 & 3,06 & 4,67 & 7,11 & 4,11 & 6,50 & 7,17 & 4,83 & 7,00 \\
\hline $\mathbf{5}$ & 5,57 & 2,86 & 4,29 & 6,33 & 3,43 & 4,71 & 7,29 & 3,81 & 6,76 & 7,86 & 4,29 & 7,14 \\
\hline $\begin{array}{c}\text { Jumlah } \\
\text { Skor }\end{array}$ & 25,19 & 13,48 & 19,24 & 27,65 & 17,05 & 22,88 & 34,23 & 19,64 & 31,61 & 35,64 & 22,45 & 34,95 \\
\hline $\begin{array}{c}\text { Rata- } \\
\text { Rata } \\
\text { Skor }\end{array}$ & 5,04 & 2,70 & 3,85 & 5,53 & 3,41 & 4,58 & 6,85 & 3,93 & 6,32 & 7,13 & 4,49 & 6,99 \\
\hline
\end{tabular}

Tabel di atas menunjukkan perolehan skor tiap indikator keterampilan literasi informasi siswa yang dilihat melalui pengerjaan tugas baik secara individu maupun kelompok. Hasil skor pada tabel diatas diperoleh dari rata-rata jumlah poin siswa perkelompok pada setiap indikator di setiap siklusnya. Indikator yang peneliti tentukan berjumlah tiga, setiap indikator mempunyai sub tersendiri. Indikator pertama yaitu menggunakan teknologi digital untuk mengakses dan menciptakan informasi guna mengembangkan pengetahuan dengan sub indikator yakni siswa mencari informasi yang beragam, siswa menggunakan blog/internet sebagai sumber informasi, siswa mampu menyeleksi informasi mana yang boleh dan tidak boleh digunakan.

Kemudian indikator kedua yaitu menggunakan informasi yang dapat dipertanggungjawabkan dengan sub indikator yakni siswa menyeleksi informasi berdasarkan konfirmasi atau diskusi dengan guru maupun teman sebaya, dan siswa mampu mencantumkan sumber informasi dengan benar. Sedangkan indikator ketiga yaitu kemampuan untuk mengakses dan menggunakan informasi dari berbagai sumber dengan sub indikator yakni siswa dapat memanfaatkan sumber yang tersedia (buku ataupun internet), siswa dapat menulis dan merangkum informasi yang dia dapat, serta siswa dapat mengkomunikasikannya pada 
orang lain menggunakan bahasanya sendiri. Penilaian skor sub indikator mulai skor satu hingga tiga dengan kriteria kurang, cukup, dan baik. Acuan penilaian setiap sub indikator dapat dilihat melalui rubrik penilaian (terlampir dalam lampiran). Pemaparan mengenai tabel perolehan skor tiap indikator keterampilan literasi informasi yang diamati melalui pemberian tugas dapat dijelaskan sebagai berikut:

Pertama, indikator menggunakan teknologi digital untuk mengakses dan menciptakan informasi guna mengembangkan pengetahuan dengan tiga sub indikator yakni siswa mencari informasi yang beragam, siswa menggunakan blog/internet sebagai sumber informasi, siswa mampu menyeleksi informasi mana yang boleh dan tidak boleh digunakan. Pada siklus I, kemampuan siswa dalam mencari informasi yang beragam, menggunakan blog/internet sebagai sumber informasi, menyeleksi informasi mana yang boleh dan tidak boleh digunakan masih tergolong rendah. Hal ini dapat dilihat dari tugas individu yang siswa kerjakan, di mana siswa hanya menggunakan satu sumber dalam mencari informasi, pada sisklus I siswa masih terpaku pada buku paket sejarah yang mereka punya. Hanya beberapa siswa saja yang menggunakan sumber internet itupun dengan cara penulisan yang masih asal-asalan. Pada sisklus I ratarata siswa belum bisa memenuhi indikator menggunakan blog/internet sebagai sumber informasi, menyeleksi informasi mana yang boleh dan tidak boleh digunakan. Pada siklus II tindakan I keterampilan siswa dalam mencari informasi yang beragam, menggunakan blog/internet sebagai sumber informasi, menyeleksi informasi mana yang boleh dan tidak boleh digunakan mengalami kenaikan namun tidak begitu signifikan, karena hanya beberapa siswa saja yang mulai menggunakan internet dalam mengerjakan tugas. Akhirnya guru melakukan tindakan II siklus II dengan cara mengelompokkan siswa. Pada tindakan II siklus II keterampilan siswa dalam mencari informasi yang beragam, menggunakan blog/internet sebagai sumber informasi, menyeleksi informasi mana yang boleh dan tidak boleh digunakan, mengalami kenaikkan hal ini dibuktikan ketika siswa mengerjakan tugas secara kelompok sumber informasi yang mereka gunakan sudah 
mulai beragam, setiap kelompok sudah dapat membedakan informasi yang boleh dan tidak boleh digunakan. Hal ini karena peneliti melihat selain berdiskusi dengan teman satu kelompoknya beberapa siswa juga bertanya kepada guru terkait sumber yang mereka gunakan. Sampai dengan tindakan III siklus II kemampuan siswa dalam mencari informasi yang beragam, menggunakan blog/internet sebagai sumber informasi, menyeleksi informasi mana yang boleh dan tidak boleh digunakan tidak mengalami peningkatan yang signifikan. Kemudian pada tindakan I siklus III guru menyediakan beberapa buku sebagai sumber literasi siswa, dan menunjukan hasil yang sangat meningkat. Hasil tersebut konstan hingga tindakan II siklus III, dan menurun pada tindakan III siklus III. Hal ini dikarenakan siswa mengerjakan tugas secara individu sehingga dalam mencari informasi yang beragam, menggunakan blog/internet sebagai sumber informasi, menyeleksi informasi mana yang boleh dan tidak boleh digunakan mengalami penurunan. Kemudian kembali meningkat pada tindakan I siklus IV yang ditunjukkan hasil kerja kelompok siswa yang kembali mengggunakan informasi yang beragam, seperti menggunakan blog/internet sebagai sumber informasi, kemudian menyeleksi informasi mana yang boleh dan tidak boleh digunakan dengan melakukan diskusi kepada guru dan teman satu kelompoknya.

$$
\text { Kedua, }
$$
indikator menggunakan informasi yang dapat dipertanggungjawabkan dengan sub indikator yakni siswa menyeleksi informasi berdasarkan konfirmasi atau diskusi dengan guru maupun teman sebaya, dan siswa mampu mencantumkan sumber informasi dengan benar. Pada tindakan I siklus I hanya ada satu atau dua orang siswa yang benar-benar bertanya kepada guru atau teman, serta mampu mencantumkan sumber informasi dengan benar, sehingga dapat dikatakan bahwa pada tindakan I siklus I kemampuan siswa dalam menyeleksi informasi berdasarkan konfirmasi atau diskusi dengan guru maupun teman sebaya, dan mampu mencantumkan sumber informasi dengan benar masih sangat kurang. Dan meskipun terus mengalami kenaikan di setiap tindakan dan siklusnya dari tindakan I siklus II 
hingga tindakan I siklus IV, dalam hal menyeleksi informasi berdasarkan konfirmasi atau diskusi dengan guru maupun teman sebaya, dan mampu mencantumkan sumber informasi dengan benar guru harus selalu membantu siswa dalam mencari informasi yang dapat digunakan serta selalu mengingatkan siswa dalam hal mencantumkan sumber yang mereka pergunakan.

Ketiga, indikator Kemudian indikator ketiga yaitu kemampuan untuk mengakses dan menggunakan informasi dari berbagai sumber dengan sub indikator yakni siswa dapat memanfaatkan sumber yang tersedia (buku ataupun internet), siswa dapat menulis dan merangkum informasi yang dia dapat, serta siswa dapat mengkomunikasikannya pada orang lain menggunakan bahasanya sendiri. Sama halnya dengan indikator pertama, pada tindakan I siklus I siswa belum mampu memanfaatkan sumber yang tersedia seperti buku ataupun internet, siswa masih sangat terpaku pada buku paket yang mereka punya.

Siswa belum mampu memanfaatkan sumber buku yang terdapat di perpustakaan sekolah ataupun sumber dari internet. Dalam segi penulisan pun siswa belum mampu mengkomunikasikannya pada orang lain menggunakan bahasanya sendiri, dalam segi penulisan siswa hanya menulis jawaban yang bersifat copypaste. Sama halnya dengan tindakan I siklus I pada tindakan I siklus II kemampuan siswa dalam hal mempergunakan sumber dan mengkomunikasikannya masih belum mengalami kenaikkan yang signifikan. Kemudian pada tindakan I siklus III guru menyediakan beberapa buku sebagai sumber literasi siswa, dan menunjukan hasil yang sangat meningkat. Hasil tersebut konstan hingga tindakan II siklus III, dan menurun pada tindakan III siklus III. Hal ini dikarenakan siswa mengerjakan tugas secara individu sehingga dalam memanfaatkan sumber yang tersedia seperti buku ataupun internet siswa merasa kesulitan dibanding ketika siswa bersama kelompoknya. Hingga pada tindakan I siklus IV peneliti melakukan perbaikan dan hasilnya pun kembali meningkat meskipun tidak terlalu signifikan. Dalam hal menulis dan merangkum informasi yang dia dapat, serta siswa dapat mengkomunikasikannya pada orang lain menggunakan bahasanya sendiri di setiap siklusnya siswa mengalami 
peningkatan meskipun guru harus dengan sabar dan telaten mengatur siswa agar siswa tidak hanya copypaste dari sumber yang ia dapatkan, serta aktif dalam diskusi maupun ketika pembelajaran sedang berlangsung.
Selain dalam bentuk tabel, berikut akan disajikan gambar diagram perkembangan indikator keterampilan literasi informasi siswa melalui pengerjaan tugas :

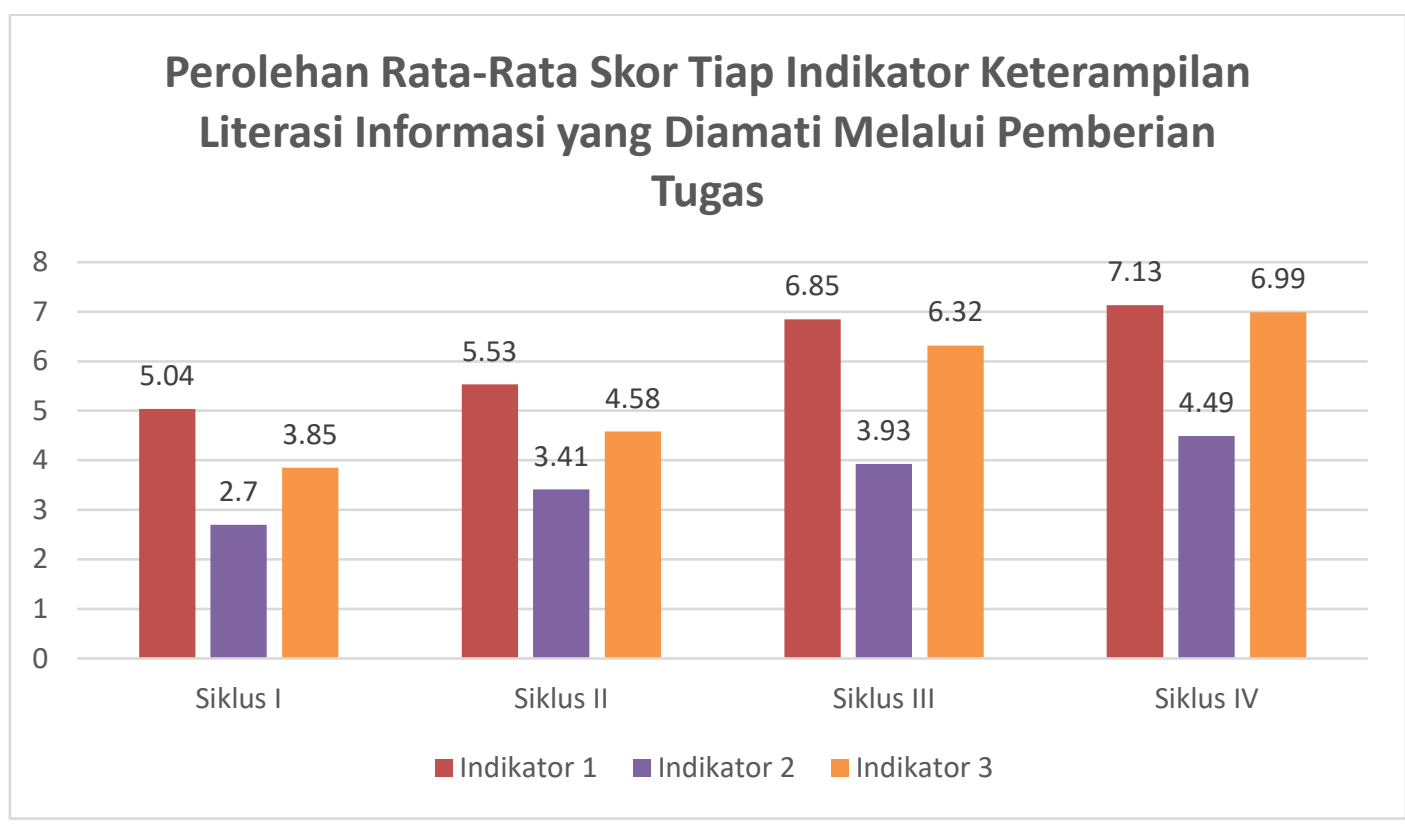

Gambar 1.2. Grafik Perolehan Skor Tiap Indikator Keterampilan Literasi Informasi Yang Diamati Melalui Pemberian Tugas

Grafik tersebut merupakan beragam, siswa menggunakan gambaran mengenai perolehan ratablog/internet sebagai sumber rata skor tiap indikator keterampilan informasi, siswa mampu menyeleksi literasi informasi yang diamati melalui informasi mana yang boleh dan tidak pemberian tugas dari siklus I hingga boleh digunakan. Kemudian indikator siklus IV. Indikator pertama yaitu kedua yaitu menggunakan informasi menggunakan teknologi digital untuk mengakses dan menciptakan yang dapat dipertanggungjawabkan informasi guna mengembangkan dengan sub indikator yakni siswa menyeleksi informasi berdasarkan pengetahuan dengan sub indikator yakni siswa mencari informasi yang konfirmasi atau diskusi dengan guru maupun teman sebaya, dan siswa 
mampu mencantumkan sumber informasi dengan benar. Sedangkan indikator ketiga yaitu kemampuan untuk mengakses dan menggunakan informasi dari berbagai sumber dengan sub indikator yakni siswa dapat memanfaatkan sumber yang tersedia (buku ataupun internet), siswa dapat menulis dan merangkum informasi yang dia dapat, serta siswa dapat mengkomunikasikannya pada orang lain menggunakan bahasanya sendiri. Grafik tersebut menunjukkan bahwa terjadi peningkatan skor ratarata setiap indikator dari siklus I hingga siklus IV. Sehingga dapat dikatakan bahwa penerapan metode In The News yang diimplementasikan kedalam pembelajaran sejarah melalui ugas-tugas yang guru berikan secara kelompok maupun individu dapat meningkatkan kemampuan literasi informasi siswa.

Dalam penelitian yang peneliti lakukan terlihat perkembangan yang signifikan dari tidakan I siklus I hingga tindakan I siklus IV. Hali ini membuktikan bahwa siswa kelas XI MIIA 2 memiliki kemampuan yang terus meningkat dalam hal keterampilan literasi informasi. Seperti yang diungkapkan oleh
Machmudah dan Rosyidi (2008, hlm. 123-124) :

Active learning mencoba membuktikan bahwa semua anak mempunyai potensi untuk berkembang sesuai fasefasenya. Dengan active learning potensi siswa dapat terus berkembang dengan dilihat dari tingkat kreatifitasnya dan tentu saja dalam memecahkan masalah.

Keunggulan metode In The News menurut Silberman yaitu menjadikan peserta didik terlibat dan menumbuhkan ketertarikan mereka pada topik yang akan dibahas. Metode ini juga akan menghasilkan kekayaan materi dan informasi bagi peserta didik karena dalam metode ini peserta didik diharuskan mempunyai atau mencari informasi dari buku, surat kabar, artikel, atau sumber informasi lainnya.

Secara umum, terdapat beberapa peningkatan yang bisa di amati dari aktivitas siswa di dalam pembelajaran setelah diterapkannya metode In The News yakni diantaranya, pertama siswa tidak lagi terpaku pada satu sumber informasi dalam hal ini buku paket sejarah saja untuk menjawab setiap permasalahan yang berkaitan dengan kegiatan belajarnya melainkan mereka mencari 
informasi dari sumber informasi lainnya sebagai pembanding dari sumber informasi yang didapatkannya sehingga tidak lagi terjebak pada informasi yang salah. Kedua, siswa sudah terbiasa mencantumkan sumber informasi yang di gunakan di dalam daftar pustaka tugas yang mereka kerjakan. Pencantuman sumber informasi merupakan salah satu aktivitas yang mendukung tercapainya indikator keterampilan literasi informasi yang peneliti tentukan. Ketiga, siswa mampu memilih sumber informasi mana yang dapat digunakan sebagai referensi informasi untuk memenuhi kegiatan belajarnya. Dalam hal ini siswa mampu membedakan sumber informasi yang dapat dipergunakan dan tidak dapat dipergunakan, siswa dapat mengidentifikasi sumber informasi dari internet (blog) mana yang dapat dipercaya dan tidak kebenaran isinya. Keempat, siswa mampu mengolah informasi dari berbagai sumber yang mereka dapat dengan tidak hanya bersifat copy paste dalam bentuk tulisan maupun lisan melainkan dengan cara mengkomunikasikannya dengan bahasnya atau sepemahamannya sendiri. Kelima, ketika berpendapat siswa tidak hanya asal berbicara, siswa sudah mulai menggunakan sumber informasi yang ia dapat sebagai rujukan apa yang ia ungkapkan dalam berbicara, dalam hal ini minimal ketika guru bertanya siswa mampu menjawab dari mana informasi yang ia ungkapkan di dapat. Misalnya siswa mendapatkan informasi dari buku, artikel, internet ataupun dari orang lain.

Secara sederhana peningkatan literasi informasi melalui metode In The News yaitu peserta didik diajarkan dan diharuskan untuk mencari informasi yang berkaitan dengan tema pembelajaran dari berbagai sumber. Tidak hanya dari internet siswa juga diharuskan menggunakan sumber buku. Dan materi yang diambil dari internet pun harus materi yang sumber tulisan ataupun penulisnya jelas. Setelah itu dengan sistem tanya jawab dan diskusi siswa pun diharuskan agar informasi atau materi yang ia dapat, ditulis atau diutarakan menurut apa yang ia pahami dan dengan bahasanya sendiri. Hal ini akan menjadikan siswa lebih kritis dalam menanggapi sebuah informasi dan menjadikan siswa lebih aktif di dalam proses pembelajaran karena mau tidak mau siswa akan mengkritisi informasi yang ia dapatkan maupun yang siswa lain 
utarakan. Intinya melalui metode In The News dapat meningkatkan literasi informasi yang mencakup keterampilan mencari informasi, keterampilan mengidentifikasi informasi, keterampilan mengolah informasi, dan keterampilan mengkomunikasikan informasi.

Hal-hal di atas menunjukkan bahwa terjadi perubahan yang baik pada keterampilan literasi informasi siswa pada pembelajaran sejarah setelah diterapkannya metode In The News dengan langkah mengerjakan soal latihan dan diskusi kelas yang membahas tema yang guru berikan pada setiap kelompoknya. Siswa kelas XI MIIA 2 SMA Kartika XIX-1 Bandung dapat mengerjakan dengan baik. Mengerjakan soal latihan dan diskusi kelas yang membahas tema yang guru berikan pada setiap kelompok ternyata dapat mendorong siswa untuk mencari informasi dari berbagai sumber informasi yang tersedia secara mandiri ataupun berkelompok sehingga hal tersebut dapat meningkatkan keterampilan literasi informasi siswa dalam pembelajaran sejarah.

\section{SIMPULAN}

Berdasarkan uraian pembahasan keseluruhan tindakan penelitian yang telah dilakukan, diperoleh kesimpulan sebagai berikut:

Pertama, perencanaan yang dilakukan oleh peneliti sebelum menerapkan metode In The News antara lain, diawali dengan melakukan observasi pra penelitian dalam pembelajaran sejarah di kelas XI MIIA 2 dan menemukan berbagai permasalahan yang menunjukkan rendahnya keterampilan literasi informasi siswa dalam pembelajaran tersebut. Selanjutnya, peneliti mulai merencanakan penerapan metode In The News sebagai cara yang digunakan untuk meningkatkan keterampilan literasi informasi siswa di kelas XI MIIA 2.

Kedua, penerapan metode In The News sebagai upaya meningkatkan keterampilan literasi informasi siswa dalam pembelajaran sejarah di kelas XI MIIA 2 SMA Kartika XIX-1 Bandung, di mana siklus I terdiri dari I tindakan, siklus II terdiri dari III tindakan, siklus III terdiri dari III tindakan, dan siklus IV terdiri dari I tindakan.

Format pada setiap siklus dibuat secara beragam. Tugas maupun 
media pembelajaran yang dirancang dalam berbagai cara ini ditujukan agar siswa tidak merasa jenuh dalam melaksanakan pembelajaran menggunakan metode In The News sehingga mereka dapat mencapai hasil penilaian maksimal.

Ketiga, berdasarkan hasil pengamatan terhadap keseluruhan data yang dipaparkan pada pembahasan, menunjukkan bahwa terjadi perubahan yang baik pada keterampilan literasi informasi siswa pada pembelajaran sejarah setelah diterapkannya metode In The News dengan langkah mengerjakan soal latihan dan diskusi kelas yang membahas tema yang guru berikan pada setiap kelompoknya. Siswa kelas XI MIIA 2 SMA Kartika XIX-1 Bandung dapat mengerjakan dengan baik. Mengerjakan soal latihan dan diskusi kelas ternyata dapat mendorong siswa untuk mencari informasi dari berbagai sumber informasi yang tersedia secara mandiri ataupun berkelompok sehingga hal tersebut dapat meningkatkan keterampilan literasi informasi siswa dalam pembelajaran sejarah. Maka disimpulkan bahwa penerapan metode In The News dapat meningkatkan keterampilan literasi informasi siswa dalam pembelajaran sejarah.

\section{DAFTAR PUSTAKA}

Darmawan, D. 2014. Pengembangan E-Learning: Teori dan Desain. Bandung: Remaja Rosdakarya

Djamarah. B. S. 2008. Rahasia Sukses Belajar (edisi revisi 2008). Jakarta: Rineka Cipta

Kusumah, W. \& Dwitagama, D. 2012 (cetakan kelima). Mengenal Penelitian Tindakan Kelas (edisi kedua). Jakarta : Indeks

Machmudah, U., Rosyidi, A.B. 2008. Active Learning Dalam Pembelajaran Bahasa Arab. Malang : UIN-Malang Press

Poerwanto, H. (1997). Teori Konflik dan Dinamika Hubungan antar suku-Bangsa. Jurnal Universitas Gajah Mada

Reza, M.Y. tt. "Deskripsi Literasi Informasi Pada Siswa SMA International Baccalaureate (IB) Program Diploma di Cita Hati Surabaya”. Jurnal Universitas Airlangga.

Sakti, P. P. 2014. Peningkatan Literasi Informasi Melalui Penggunaan Media Internet Dalam Pembelajaran Sejarah (Penelitian Tindakan Kelas XI IPS $B$ MAN 1 Bandung). (Skripsi). FPIPS. Universitas Pendidikan Indonesia, Bandung.

Silberman, M. 2010. Active Learning : 101 Strategies to Teach Any Subject. Jakarta: Indeks

Supriatna, N. 2007. Konstruksi Pembelajaran Sejarah Kritis. Bandung: Historia Utama Pers. 
FACTUM

Volume 6, Nomor 1, April 2017 